\title{
ASSIGNMENT OF THE HUMAN CONNEXIN43 GENE, GJAl, TO CHROMOSOME 6q22.3
}

\author{
Rumiko Kato, ${ }^{*}$ Naomichi Matsumoto, and Norio Nilkawa \\ Department of Human Genetics, Nagasaki University School of Medicine, \\ 1-12-4 Sakamoto, Nagasaki 852, Japan
}

Summary Connexin 43 is one of connexin proteins which make up the intercellular gap junctions. Targeted null mutation of the mouse connexin 43 gene has been reported to result in a cardiac malformation. Moreover, single-base mutations of the human homolog (GJAl) were identified in patients with laterality defects of the chest and abdominal organs, suggesting that connexin 43 contributes to the determination of laterality during organogenesis. We mapped $G J A l$ to $6 \mathrm{q} 22.3$ by fluorescence in situ hybridization, using a bacterial artificial chromosome (BAC) clone that covered almost the entire GJA1-cDNA, as a probe. Key Words connexin 43 gene, GJA1, 6q22.3, FISH, BAC clone

\section{INTRODUCTION}

The connexin proteins constitute intercellular channels of gap junction that permit transfer of small molecules from cell to cell (Beyer et al., 1988). Connexin 43 , a member of this gene family, is abundantly expressed in the mammalian heart and plays a role in synchronizing the heart beat rhythm (Goshima, 1971). A connexin43-gene knockout mouse has been reported to be neonatally lethal due to right ventricular outlet stenosis (Reaume et al., 1995). Single-base substitutions in the human homolog $(G J A l)$ were identified in patients with heart malformations and laterality defects (Britz-Cunningham et al., 1995), suggesting that connexin43 is participating in embryogenesis, cellular differentiation, and development of the heart. GJAI has been mapped to chromosome 6q21-q23.2 (Corcos et al., 1993). Here we isolated a bacterial artificial chromosome (BAC) clone containing GJAI and narrowed the assignment of the gene to $6 \mathrm{q} 22.3$ by fluorescence in situ hybridization.

\section{MATERIALS AND METHODS}

Isolation of BAC clone containing the human GJAl. A human BAC

Received October 25, 1996; Revised version accepted January 7, 1997.

* To whom correspondence should be addressed. 
library (Research Genetics, USA) was screened by means of polymerase chain reaction (PCR) according to the manufacturer's protocol. Two sets of primers were designed from the partial sequence of the human GJAl (Fishman et al., 1991). GJA primer sequences (sense, GCTCTGTGCTCCAAGTTACA; antisense, AGTAGTGAAGTCACGCCAAG) were designed to amplify the most part of exon 1 and a small portion of the $5^{\prime}$ untranslated region of the gene, excluding the sequence of a processed pseudogene. CXD primer sequences (sense, AGCTGCTGGACATGAATTAC; antisense, CTAGATCTCCAGGTCATCAG) were chosen from the $3^{\prime}$ portion of the GJAl-cDNA. Using GJA as a primer, PCR was performed for 30 cycles under the following conditions: denaturation at $94^{\circ} \mathrm{C}$ for $30 \mathrm{sec}$, annealing at $58^{\circ} \mathrm{C}$ for $30 \mathrm{sec}$ and extension at $72^{\circ} \mathrm{C}$ for $30 \mathrm{sec}$. The GJA-PCR products were subjected to the second PCR using CXD to evaluate whether these clones covered the entire CDNA. The PCR products using isolated BAC clones as templates were cloned with pGEM T-vector (Promega, USA) and sequenced by the dideoxy chain-termination method.

Fluorescence in situ hybridization (FISH). Chromosome preparations for FISH were made according to the method of Dutrillaux and Viegas-Pequignot (1981). In brief, cultures of peripheral blood lymphocytes were synchronized overnight by adding $0.3 \mu \mathrm{g} / \mathrm{ml} \mathrm{BrdU}$, and then by replacing with $200 \mu \mathrm{g} / \mathrm{ml}$ thymidine $6.5 \mathrm{hr}$ prior to harvest. Isolated BAC clones were labeled with biotin-16dUTP (Boehringer-Mannheim, Germany) by nick-translation. FISH was performed using human Cot-I DNA (GIBCO BRL, USA) as a competitor, and fluorescence signals were detected as described previously (Ohta et al., 1993). After observation of FISH signals, the slides were rinsed in water to remove the antifading agent and washed in $4 \times \mathrm{SSC}$ for $10 \mathrm{~min}$, and then chromosomes were re-stained with $1 \mu \mathrm{g} / \mathrm{ml}$ Hoechst 33258 in $4 \times \mathrm{SSC}$ for $10 \mathrm{~min}$. The slides mounted in phosphate buffer were exposed to $U V$ at $75^{\circ} \mathrm{C}$ for $3 \mathrm{~min}$, and subsequently stained with $4 \%$ Giemsa.

\section{RESULTS AND DISCUSSION}

By a PCR-based screening of a human BAC library using the GJA-primer set, two positive clones, $342 \mathrm{M} 16$ and $326 \mathrm{~J} 20$, were isolated. Another PCR with the CXD primers and the sequence data confirmed that both clones contained the entire $G J A 1$-cDNA sequences and of the $5^{\prime}$-UTR sequence of the true gene (data not shown). FISH with the isolated BAC showed FITC-signals on the long arm of chromosomes 6 in almost all the 50 metaphase cells observed (Fig. 1a). There were no signals on other chromosomes, especially on chromosomes 5 at which the locus for processed pseudogene of connexin43 exists (Fishman et al., 1991). Comparison of PI-stained chromosomes 6 with G-bands on the same metaphase cells revealed that the signals were consistently located to 6q22.3 (Fig. 1b). Thus, we successfully assigned the locus of expressed connexin 43 gene, GJA1, at $6 \mathrm{q} 22.3$.

Jpn J Human Genet 

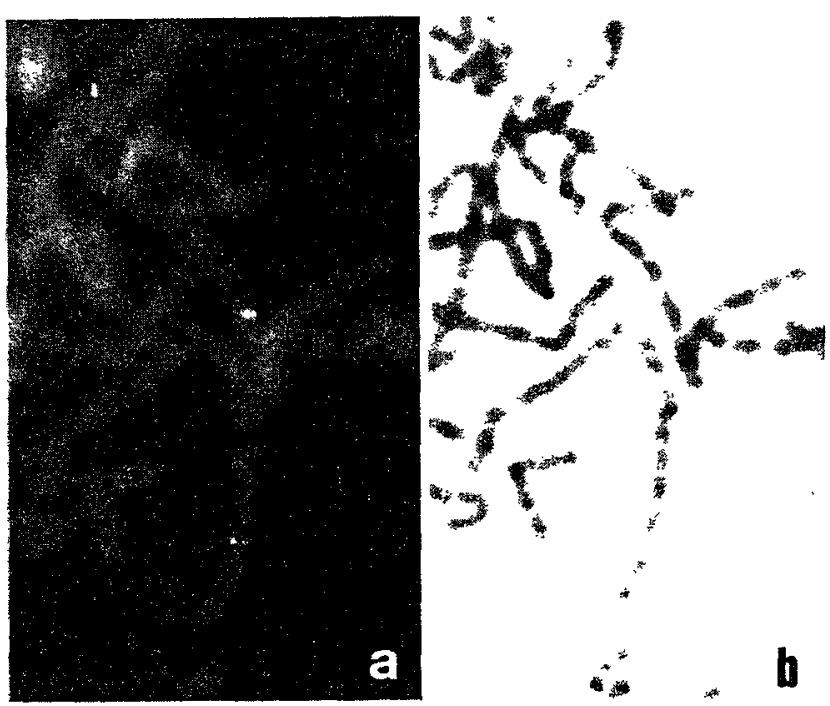

Fig. 1. FISH on human prometaphase chromosomes using a $\mathrm{BAC}$ clone containing the human connexin43 gene $(G J A I)$ as a probe. FITC-signals appear on PI-stained chromosomes (a) and location of the signals corresponds to 6q22.3 on G-banded chromosomes (b).

The expressed GJA1 has been mapped to chromosome 6 (Willecke et al., 1990; Fishman et al., 1991; Hsieh et al., 1991). By a further study with a human/ rodent somatic cell hybrid panel, GJA1 has been sublocalized to band 6q21-q23.2 (Corcos et al., 1993). Our data narrowed the GJAl localization to $6 \mathrm{q} 22.3$ and provide useful information for the further study of connexin 43 .

Contribution of connexin 43 to the determination of left-right asymmetry was recently discussed. Britz-Cunningham et al. (1995) reported single-base substitutions in the cytoplasmic tail of $G J A I$ in 6 patients with complex heart malformations and laterality defects. However, similar studies by two other groups were unsuccessful to identify any mutations in a total of 40 patients with laterality defects and/or cardiac anomalies (one patient without it) (Casey and Ballabio, 1995; Penman Splitt et al., 1995). We recently reported a patient with heterotaxia associated with a de novo balanced translocation $(6 ; 18)$ (q21 or q22;q21.3 or q22) (Kato et al., 1996). The breakpoint of the translocated chromosome 6 was near to the $G J A 1$ localization, although they seem different at the chromosome band level. It remains to be seen that $G J A l$ is disrupted in the heterotaxia patient.

\section{REFERENCES}

Beyer ED, Paul D, Goodenough DA (1988): The connexins, a family of related gap junction proteins. In: Hertzberg EL, Johnson RG (eds). Gap junctions. A.R. Liss, New York, pp 167175

Vol. 42, No. 1,1997 
Britz-Cunningham SH, Shah MM, Zuppan CW, Fletcher WH (1995): Mutations of the connexin 43 gap-junction gene in patients with heart malformations and defects of laterality. $\mathrm{N}$ Engl J Med 332: 1323-1329

Casey B, Ballabio A (1995): Connexin43 mutations in sporadic and familial defects of laterality. N Engl J Med 333: 941

Corcos IA, Meese EU, Loch-Caruso R (1993): Human connexin43 gene locus, GJA1, sublocalized to band 6q21-q23.2. Cytogenet Cell Genet 64: 31-32

Dutrillaux B, Viegas-Pequignot E (1981): High resolution R- and G-banding on the same preparation. Hum Genet 57: 93-95

Fishman GI, Eddy RL, Shows TB, Rosenthal L, Leinwand LA (1991): The human connexin gene family of gap junction proteins: distinct chromosomal locations but similar structures. Genomics 10: 250-256

Goshima K (1971): Synchronized beating of myocardial cells mediated by FL cells in monolayer culture and its inhibition by trypsin-treated FL cells. Exp Cell Res 65: 161-169

Hsieh C-L, Kumar NM, Gilula NB, Francke U (1991): Distribution of genes for gap junction membrane channel proteins on human and mouse chromosomes. Somatic Cell Mol Genet 17: $191-200$

Kato R, Yamada Y, Niikawa N (1996): De novo balanced translocation $(6 ; 18)(q 21 ; q 21.3)$ in a patient with heterotaxia. Am J Med Genet 66: 184-186

Ohta T, Tohma T, Soejima H, Fukushima Y, Nagai T, Yoshiura K, Jinno Y, Niikawa N (1993): The origin of cytogenetically unidentifiable chromosome abnormalities: six cases ascertained by targeted chromosome-band painting. Hum Genet 92: 1-5

Penman Splitt M, Burn J, Goodship J (1995): Connexin43 mutations in sporadic and familial defects of laterality. N Engl J Med 333: 941

Reaume AG, de Sousa PA, Kulkarni S, Langille BL, Zhu D, Davies TC, Juneja SC, Kidder GM, Rossant $\mathbf{J}$ (1995): Cardiac malformation in neonatal mice lacking connexin43. Science $\mathbf{2 6 7}$ $1831-1834$

Willecke K, Jungbluth S, Dahl E, Hennemann H, Heynkes R, Grzeschik K-H (1990): Six genes of the human connexin gene-family coding for gap junctional proteins are assigned to four different human chromosomes. Eur J Cell Biol 53: 275-280 